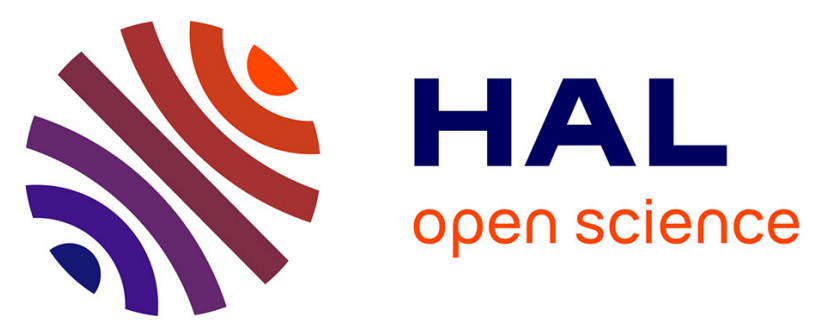

\title{
Absence of influence of gender and BMPR2 mutation type on clinical phenotypes of pulmonary arterial hypertension.
}

Barbara Girerd, David Montani, Mélanie Eyries, Azzedine Yaici, Benjamin Sztrymf, Florence Coulet, Olivier Sitbon, Gérald Simonneau, Florent Soubrier, Marc Humbert

\section{To cite this version:}

Barbara Girerd, David Montani, Mélanie Eyries, Azzedine Yaici, Benjamin Sztrymf, et al.. Absence of influence of gender and BMPR2 mutation type on clinical phenotypes of pulmonary arterial hypertension.. Respiratory Research, 2010, 11 (1), pp.73. 10.1186/1465-9921-11-73 . inserm-00668454

\section{HAL Id: inserm-00668454 https://www.hal.inserm.fr/inserm-00668454}

Submitted on 9 Feb 2012

HAL is a multi-disciplinary open access archive for the deposit and dissemination of scientific research documents, whether they are published or not. The documents may come from teaching and research institutions in France or abroad, or from public or private research centers.
L'archive ouverte pluridisciplinaire HAL, est destinée au dépôt et à la diffusion de documents scientifiques de niveau recherche, publiés ou non, émanant des établissements d'enseignement et de recherche français ou étrangers, des laboratoires publics ou privés. 


\title{
Absence of influence of gender and BMPR2 mutation type on clinical phenotypes of pulmonary arterial hypertension
}

\author{
Barbara Girerd1,2,3, David Montani*1,2,3, Mélanie Eyries4 ${ }^{4}$ Azzedine Yaici1,2,3, Benjamin Sztrymf1,2,3, Florence Coulet4, \\ Olivier Sitbon 1,2,3, Gérald Simonneau1,2,3, Florent Soubrier ${ }^{4}$ and Marc Humbert1,2,3
}

\begin{abstract}
Background: Previous studies indicate that patients with pulmonary arterial hypertension (PAH) carrying a mutation in the bone morphogenetic protein receptor type 2 (BMPR2) gene, develop the disease 10 years earlier than non-carriers, and have a more severe hemodynamic compromise at diagnosis. A recent report has suggested that this may only be the case for females and that patients with missense mutations in BMPR2 gene have more severe disease than patients with truncating mutations.
\end{abstract}

Methods: We reviewed data from all patients with PAH considered as idiopathic and patients with a family history of PAH, who underwent genetic counselling in the French PAH network between January, 1st 2004 and April, 1st 2010. We compared clinical, functional, and hemodynamic characteristics between carriers and non-carriers of a BMPR2 mutation, according to gender or BMPR2 mutation type.

Results: PAH patients carrying a BMPR2 mutation $(n=115)$ were significantly younger at diagnosis than non-carriers $(n$ $=267$ ) (35.8 \pm 15.4 and $47.5 \pm 16.2$ respectively, $\mathrm{p}<0.0001)$. The presence of a $B M P R 2$ mutation was associated with a younger age at diagnosis in females (36.4 \pm 14.9 in BMPR2 mutation carriers and $47.4 \pm 15.8$ in non-carriers, $p<0.0001$ ), and males (34.6 \pm 16.8 in BMPR2 mutation carriers and $47.8 \pm 17.1$ in non-carriers, $\mathrm{p}<0.0001$ ). BMPR2 mutation carriers had a more severe hemodynamic compromise at diagnosis, but this was not influenced by gender. No differences in survival and time to death or lung transplantation were found in male and female PAH patients carrying a BMPR2 mutation. No differences were observed in clinical outcomes according to the type of BMPR2 mutations (missense, truncating, large rearrangement or splice defect).

Conclusion: When compared to non-carriers, BMPR2 mutation carriers from the French PAH network are younger at diagnosis and present with a more severe hemodynamic compromise, irrespective of gender. Moreover, BMPR2 mutation type had no influence on clinical phenotypes in our patient population.

\section{Background}

Pulmonary arterial hypertension (PAH) is a severe disease affecting small pulmonary arteries, with a progressive remodeling leading to elevated pulmonary vascular resistance and right ventricular failure [1-3]. PAH can be idiopathic, heritable or associated with drug or toxin exposure or other conditions such as connective tissue diseases, human immunodeficiency virus infection, congenital heart diseases, and portal hypertension [1,2]. Ger-

* Correspondence: david.montani@abc.aphp.fr

1 Faculté de Médecine, Université Paris-Sud, Kremlin-Bicêtre, F-94276, France Full list of author information is available at the end of the article mline mutations in the bone morphogenetic protein receptor type 2 (BMPR2) gene are detected in 10 to $40 \%$ of idiopathic PAH and in $58 \%$ to $74 \%$ of patients with a family history of PAH [4-6]. Accumulated evidence indicates that PAH patients carrying a BMPR2 mutation develop PAH approximately 10 years earlier than noncarriers, with a more severe hemodynamic compromise at diagnosis, and are less likely to respond to acute vasodilator testing [4-6]. In addition, few cases of PAH in ACVRL1 and Endoglin mutants have been reported [6-9]. PAH patients with an ACVRL1 mutation are characterized by a younger age at diagnosis and death, as com- 
pared to PAH patients without BMPR2 and ACVRL1 mutation [6].

A recent report in Respiratory Research by Austin and colleagues [10] showed that PAH patients with missense mutations in BMPR2 gene had more severe disease than patients with truncating mutation with a significant younger age at diagnosis, a younger age at death and a shorter survival from diagnosis to death or lung transplantation. Moreover, they demonstrated a statistically significant difference in age at diagnosis between carriers and non-carriers, and subgroup analysis revealed this to be the case only for females [10]

To test the influence of gender in patients from the French PAH network, we decided to compare clinical, functional, and hemodynamic characteristics between PAH patients carriers of a BMPR2 mutation and patients without identified mutation, according to gender. To analyse the influence of the type of BMPR2 mutation in clinical outcomes of PAH, clinical phenotypes were compared between BMPR2 missense mutation carriers, $B M P R 2$ truncating mutation carriers and patients carriers of a large rearrangement or a splice defect in the $B M P R 2$ gene.

\section{Methods}

\section{Patients}

We reviewed data from all patients with PAH considered to be idiopathic and patients with a family history of PAH, who were tested for BMPR2 and ACVRL1 mutations, seen in the French PAH network (Université ParisSud 11, Hôpital Antoine-Béclère, Clamart, France) between January, $1^{\text {st }} 2004$ and April, $1^{\text {st }} 2010$. In accordance with the guidelines of the American College of Chest Physicians [11], patients tested for BMPR2 or $A C V R L 1$ mutations signed written informed consent and underwent genetic counselling. A diagnosis of PAH was defined by hemodynamic measurement during rightheart catheterization (see below). Idiopathic PAH was recognized after ruling out all causes of pulmonary hypertension, summarized in the revised classification, and by determining no other PAH cases in the family [4]. Familial PAH was recognised if there was more than one confirmed case in the family. PAH patients with an ACVRL1 mutation ( $\mathrm{n}=9$ ), a suspected or confirmed pulmonary veno-occlusive disease $(\mathrm{n}=55)$, or a family history of PAH without identification of either BMPR2 or ACVRL1 mutation $(\mathrm{n}=13)$ were excluded in order to limit the risk of misclassification. All clinical characteristics at PAH diagnosis and follow-up were stored in the Registry of the French PAH Network [12]. This Registry was set up in agreement with French bioethics laws (French Commission Nationale de l'Informatique et des libertés), and patients gave their consent to be included $[4,12]$.

Hemodynamic measurements and 6-minute walk distance $\mathrm{PAH}$ was defined as a mean pulmonary arterial pressure (mPAP) $\geq 25 \mathrm{mmHg}$ associated with a normal pulmonary capillary wedge pressure (PCWP). Hemodynamic evaluation by right heart catheterization was performed at baseline in all subjects according to our previously described protocol $[13,14]$. Patients with left heart diseases and passive increase of mPAP secondary to increase cardiac output were excluded from the study. The mPAP, PCWP, right atrial pressure (RAP) and mixed venous oxygen saturation $\left(\mathrm{SvO}_{2}\right)$ were recorded during right-heart catheterization. Cardiac output (CO) was measured by the standard thermodilution technique. The cardiac index (CI) was calculated as the $\mathrm{CO}$ divided by the body surface area and systolic index as the CI divided by cardiac frequency. Indexed total pulmonary resistance (TPRi) and indexed pulmonary vascular resistance (PVRi) were calculated as (mPAP)/CI and (mPAP-PCWP)/CI respectively, and results were expressed as $\mathrm{mmHg} / \mathrm{L} / \mathrm{min} / \mathrm{m}^{2}$. Baseline hemodynamic data and response to short-term vasodilator nitric oxide (NO) obtained through right heart catheterization were performed for all subjects. A NO challenge (10 ppm for 5-10 minutes) was used and a positive acute response was defined as a decrease in mPAP of more than $10 \mathrm{mmHg}$ compared to the baseline mPAP to reach a mPAP lower than $40 \mathrm{mmHg}$ associated with a normal or increased $\mathrm{CO}$, as previously described $[1,2,13]$. A non-encouraged 6 -minute walk test according to the American Thoracic Society recommendations was performed [15].

\section{Screening of point mutations and large rearrangements of $A C V R L 1$ and $B M P R 2$ genes}

Human genomic DNA was prepared from whole blood samples. Amplification of the entire coding sequence and intronic junctions of the $A C V R L 1$ and BMPR2 genes was performed on $50 \mathrm{ng}$ of genomic DNA from each individual. Genetic variation of $B M P R 2$ and $A C V R L 1$ sequence and rearrangements of one or more exons of the ACVRL1 and $B M P R 2$ genes was detected as previously described $[4,6]$.

\section{Statistical analysis}

We compared demographic and clinical features, age at diagnosis of PAH, according to gender and BMPR2 mutation status, or according to type of $B M P R 2$ mutation with the use of Chi-2, ANOVA post Hoc test and Mann Whitney as appropriate. Survival and time to death or lung transplantation were analysed with the use of Kaplan 
Meier Analysis. A p value of less than 0.05 was considered to indicate statistical significance.

\section{Results}

\section{Influence of gender on phenotypes}

In the French PAH network, 382 PAH patients with idiopathic $\mathrm{PAH}$ or with a family history of $\mathrm{PAH}$, corresponding to 113 males and 269 females, were screened for BMPR2 mutations. Interestingly, the same proportion of $B M P R 2$ mutation carriers was observed in males $(\mathrm{n}=33$, $30.1 \%)$ and females $(\mathrm{n}=81,30.1 \%)$. As previously reported $[4,6,10]$, PAH patients carrying a BMPR2 mutation were significantly younger at diagnosis than non-carriers $(35.8 \pm 15.4$ and $47.5 \pm 16.2, \mathrm{p}<0.0001)$. This was the case in females (36.4 \pm 14.9 in BMPR2 mutation carriers and $47.4 \pm 15.8$ in non-carriers, $\mathrm{p}<0.0001$ ) (Figure 1 ), as well as in males (34.6 \pm 16.8 in BMPR2 mutation carriers and $47.8 \pm 17.1$ in non-carriers, $\mathrm{p}<0.0001$ ) (Figure 1).
As previously reported [4,6], BMPR2 mutation carriers had a more severe hemodynamic compromise at diagnosis, but this was not influenced by gender (Table 1). Although BMPR2 mutation carriers are younger at diagnosis than non-carriers, survival and time to death or lung transplantation is broadly similar between carriers and non-carriers, suggesting a similar evolution of established disease in heritable and idiopathic PAH (Figure 2A). When comparing survival and time to death or lung transplantation in BMPR2 mutation carriers and noncarriers according to gender, no statistically significant differences were observed between males and females (Figure 3A and 3B). Although males and females have the same age at diagnosis $(43.8 \pm 18.0$ and $44.2 \pm 16.3$ respectively, $\mathrm{p}=0.86)$, and have also the same age at death $(50.4$ \pm 22.9 and $49.0 \pm 16.9$ respectively, $p=0.74$ ), we observed a trend for more severe prognosis of the disease in males with a shorter time to death or lung transplantation (Fig-

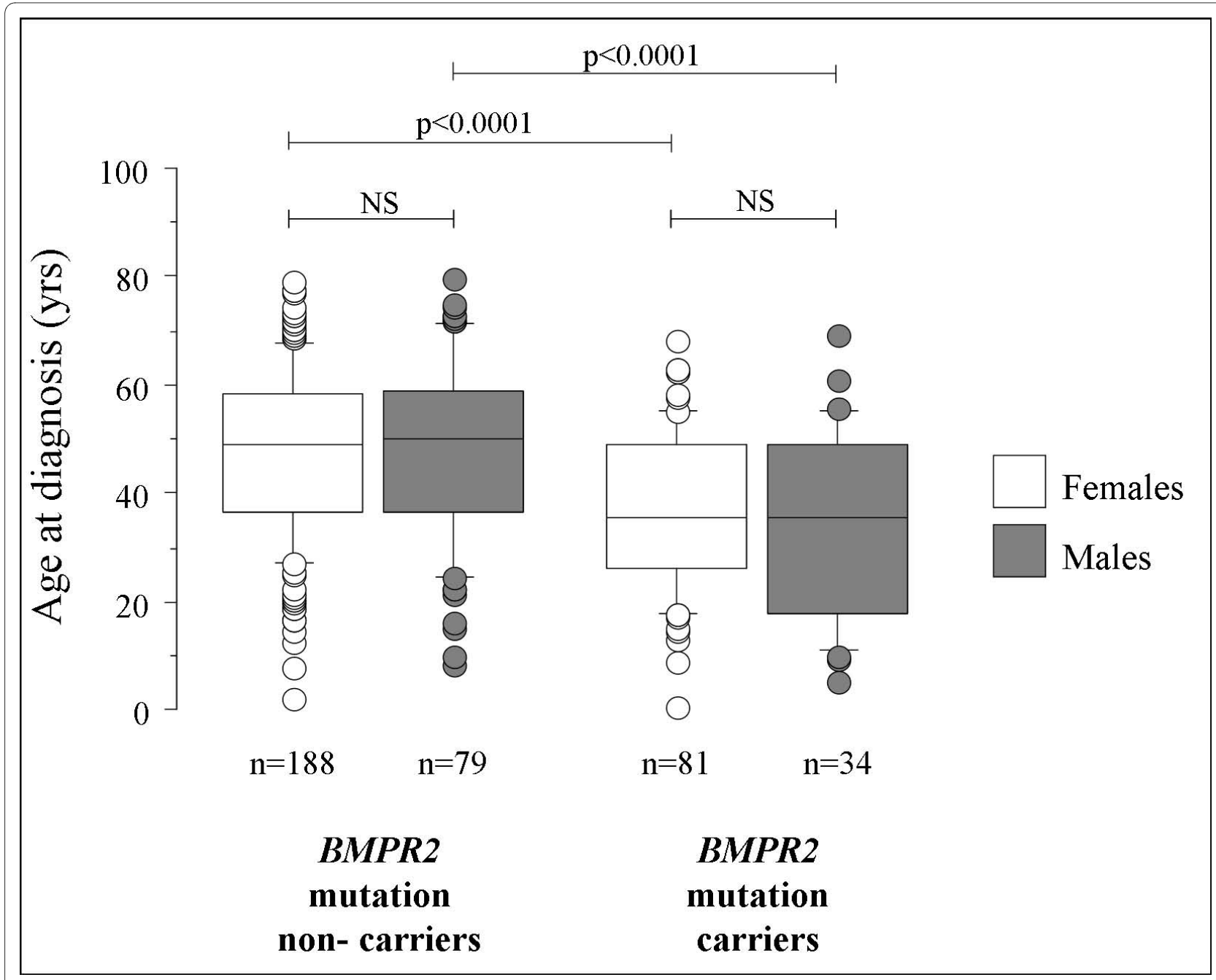

Figure 1 Age at PAH diagnosis in females and males according to BMPR2 mutation status. BMPR2: bone morphogenetic protein receptor type 2, PAH: pulmonary arterial hypertension. 
A.

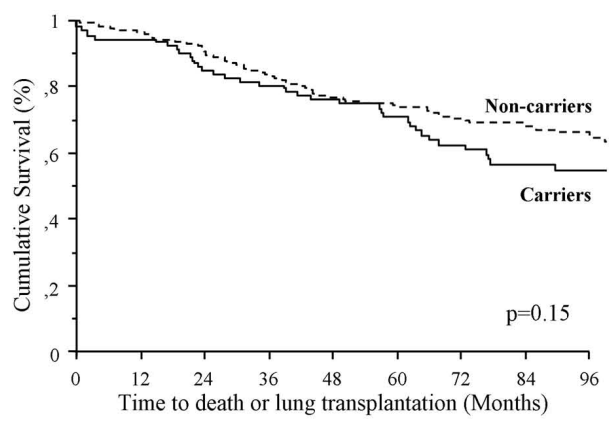

\begin{tabular}{|l|c|c|c|c|c|c|c|c|c|}
\hline Carriers & 109 & 93 & 79 & 74 & 62 & 52 & 42 & 36 & 30 \\
\hline Non-carriers & 264 & 239 & 208 & 169 & 145 & 122 & 106 & 95 & 82 \\
\hline
\end{tabular}

B.

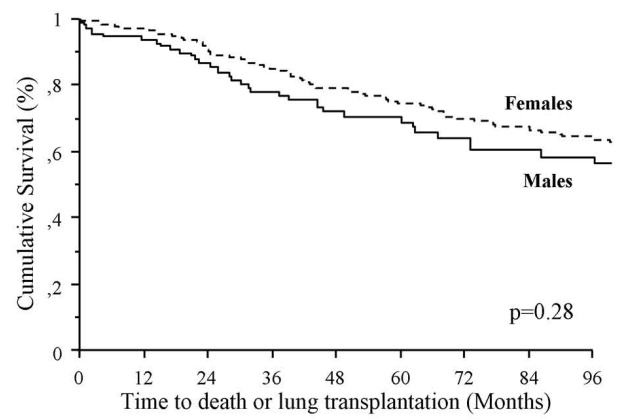

\begin{tabular}{|l|c|c|c|c|c|c|c|c|c|}
\hline $\begin{array}{l}\text { Male } \\
\text { patients }\end{array}$ & 112 & 98 & 84 & 67 & 55 & 46 & 36 & 31 & 29 \\
\hline $\begin{array}{l}\text { Female } \\
\text { patients }\end{array}$ & 261 & 234 & 203 & 176 & 153 & 129 & 112 & 100 & 83 \\
\hline
\end{tabular}

Figure 2 Time to death or lung transplantation in all patients according to BMPR2 mutation status (A) or gender (B). BMPR2: bone morphogenetic protein receptor type 2 .

ure $2 \mathrm{~B})$, and particularly in males carrying a $B M P R 2$ mutation (Figure 3A).

\section{Influence of BMPR2 mutation type on phenotypes}

At the time of analysis, 115 patients were carriers of a BMPR2 mutation. Thirty two (27.8\%) had a BMPR2 missense mutation, 51 (44.3\%) a truncating BMPR2 mutation and $32(27.8 \%)$ other BMPR2 mutations (12 splice defects and 20 large rearrangements) (Additional file 1). No differences in age at diagnosis were observed between BMPR2 missense mutation carriers, BMPR2 truncating mutation carriers and patients carrying a large rearrangement or a splice defect in the BMPR2 gene $(35.8 \pm 16.9$,
$37.3 \pm 14.0$ and $33.5 \pm 16.3$ respectively) (Table 2 ). Clinical, functional, and hemodynamic characteristics showed only a lower RAP and a higher CI in BMPR2 missense mutation carriers, when compared to BMPR2 truncating mutation carriers (Table 2). No statistically significant differences were observed in survival and time to death or lung transplantation between these 3 subgroups of BMPR2 mutation carriers (Figure 4).

\section{Discussion}

In this study, we show that BMPR2 mutation carriers are younger at diagnosis with a more severe hemodynamic
A.

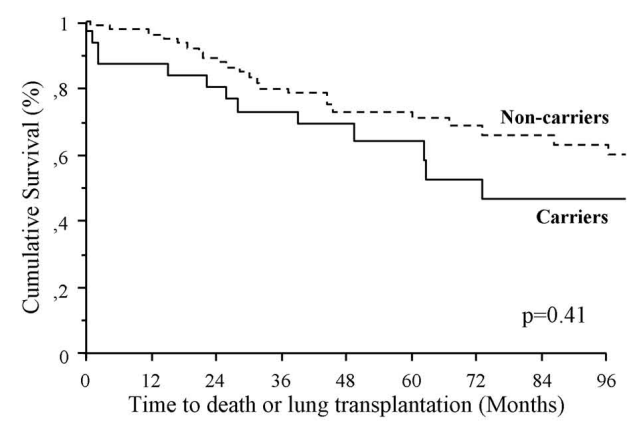

B.

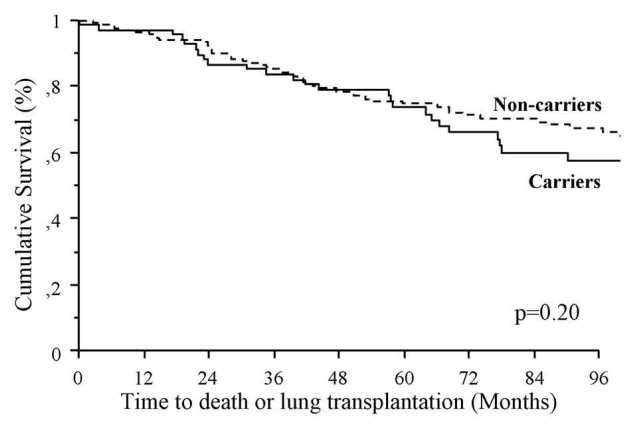

\begin{tabular}{|l|c|c|c|c|c|c|c|c|c|}
\hline $\begin{array}{l}\text { Female } \\
\text { carriers }\end{array}$ & 76 & 67 & 57 & 55 & 48 & 40 & 33 & 28 & 23 \\
\hline $\begin{array}{l}\text { Female } \\
\text { non-carriers }\end{array}$ & 185 & 167 & 146 & 121 & 105 & 89 & 79 & 72 & 60 \\
\hline
\end{tabular}

Figure 3 Time to death or lung transplantation in males (A) and in females (B) according to BMPR2 mutation status. BMPR2: bone morphogenetic protein receptor type 2 . 
Table 1: Baseline hemodynamic characteristics of male and female patients carrying a BMPR2 mutation.

\begin{tabular}{|c|c|c|c|c|c|c|}
\hline & \multicolumn{3}{|c|}{ Male patients } & \multicolumn{3}{|c|}{ Female patients } \\
\hline & $\begin{array}{c}\text { BMPR2 } \\
\text { mutation non- } \\
\text { carriers } \\
n=79\end{array}$ & $\begin{array}{c}\text { BMPR2 } \\
\text { mutation } \\
\text { carriers } \\
n=34\end{array}$ & $\mathbf{p}$ & $\begin{array}{c}\text { BMPR2 } \\
\text { mutation non- } \\
\text { carriers } \\
n=188\end{array}$ & $\begin{array}{c}\text { BMPR2 } \\
\text { mutation } \\
\text { carriers } \\
\mathbf{n}=\mathbf{8 1}\end{array}$ & $\mathbf{p}$ \\
\hline Age at diagnosis, yrs (mean \pm SD) & $47.8 \pm 17.1$ & $34.6 \pm 16.8$ & $<0.0001$ & $47.4 \pm 15.8$ & $36.4 \pm 14.9$ & $<0.0001$ \\
\hline \multicolumn{7}{|l|}{ NYHA } \\
\hline$I-I I$ & $21(26.6 \%)$ & $6(17.6 \%)$ & $<0.01$ & $27(14.4 \%)$ & $11(13.6 \%)$ & 0.90 \\
\hline III & $57(72.2 \%)$ & $21(61.8 \%)$ & & $135(71.8 \%)$ & $55(67.9 \%)$ & \\
\hline IV & $1(1.3 \%)$ & $6(17.6 \%)$ & & $20(10.6 \%)$ & $10(12.3 \%)$ & \\
\hline Six-minute walk test distance, $m$ & $394 \pm 96$ & $377 \pm 98$ & 0.49 & $328 \pm 119$ & $343 \pm 102$ & 0.35 \\
\hline mPAP, $m m H g$ & $57 \pm 14$ & $63 \pm 13$ & 0.03 & $56 \pm 14$ & $62 \pm 13$ & 0.0007 \\
\hline $\mathrm{RAP}, \mathrm{mmHg}$ & $8 \pm 5$ & $8 \pm 6$ & 0.81 & $8 \pm 5$ & $8 \pm 5$ & 0.70 \\
\hline PCWP, $m m H g$ & $9 \pm 3$ & $8 \pm 3$ & 0.39 & $8 \pm 3$ & $8 \pm 3$ & 0.84 \\
\hline $\mathrm{Cl}, \mathrm{L} / \mathrm{min} / \mathrm{m}^{2}$ & $2.71 \pm 0.83$ & $2.17 \pm 0.60$ & 0.0003 & $2.45 \pm 0.66$ & $2.07 \pm 0.62$ & $<0.0001$ \\
\hline $\mathrm{PVRi}, \mathrm{mmHg} / \mathrm{L} / \mathrm{min} / \mathrm{m}^{2}$ & $19.6 \pm 9.3$ & $21.9 \pm 13.5$ & 0.29 & $20.5 \pm 8.5$ & $25.1 \pm 11.1$ & 0.0015 \\
\hline Sv02, \% & $67 \pm 8$ & $59 \pm 9$ & 0.0015 & $61 \pm 10$ & $59 \pm 10$ & 0.09 \\
\hline Acute vasodilator responders, $\%$ & $9(11.4 \%)$ & $1(2.9 \%)$ & 0.20 & 27 (14.4\%) & $1(1.2 \%)$ & $<0.01$ \\
\hline
\end{tabular}

BMPR2: bone morphogenetic protein receptor type 2, PAH: pulmonary arterial hypertension, NYHA = New York Heart Association, mPAP = mean pulmonary artery pressure, $\mathrm{RAP}=$ right atrial pressure, $\mathrm{PCWP}=$ pulmonary capillary wedge pressure, $\mathrm{Cl}=$ cardiac index, $\mathrm{PVRi}=$ indexed pulmonary vascular resistance, $\mathrm{SvO} 2=$ mixed venous oxygen saturation, $\mathrm{NO}=$ nitric oxide.

Results are expressed as mean \pm SD

compromise, but this is not influenced by gender. However, we observed a trend for more severe prognosis of the disease in males, and particularly in male patients carrying a BMPR2 mutation. This observation is consistent with our recent observation that PAH mortality is most closely associated with male gender [16]. Moreover, we compared BMPR2 missense mutation carriers, $B M P R 2$ truncating mutation carriers and patients carrying a splice defect or a large rearrangement in the BMPR2 gene. We found no influence of mutation type on clinical phenotypes in BMPR2 mutation carriers with PAH.

Although no significant impact of gender was observed on age at diagnosis and outcomes in our patient population, it should be emphasized that PAH mostly occur in females, irrespective of $B M P R 2$ mutation status (sex ratio females/males: 2.4 in BMPR2 mutation non-carriers, and 2.4 in BMPR2 mutation carriers). To explain overrepresentation of female patients it has been suggested that estrogens and estrogen metabolism might participate in the pathogenesis of PAH $[17,18]$. Estrogen is a potent mitogen of pulmonary vascular smooth muscle cells, and cytochrome P450 1B1 (CYP1B1), highly expressed in lung and particularly in endothelial cells, catalyzes the oxidation of estrogens to 2-hydroxy (2-OHE) and 4hydroxy (4-OHE) estrogens. West et al. [17] have showed significantly decreased transcript levels of CYP1B1 in affected female compared to unaffected females with a BMPR2 mutation. They hypothesized that low level of CYP1B1 might result in increased local concentrations of estrogens, increasing the risk of PAH. Moreover, in extrahepatic tissue, oxidation of estrogens also occurs by hydroxylation at the $\mathrm{C}-16$ position by other $\mathrm{P} 450$ enzymes, predominantly resulting in $16 \alpha$-hydroxyestrone (16 $\alpha$-OHE1) which stimulates cellular proliferation by constitutively activating the estrogen receptor. Austin et al. [18] demonstrated a decrease of the 2-OHE/16 $\alpha$ OHE1 ratio in affected female compared to non-affected females with a BMPR2 mutation. Thus, altered estrogen metabolism could contribute to the penetrance of PAH in women and CYP1B1 could be a sex specific modifier gene.

Secondly, we compared clinical phenotypes of $B M P R 2$ missense mutation carriers, BMPR2 truncating mutation carriers and patients carrying a splice defect or a large 


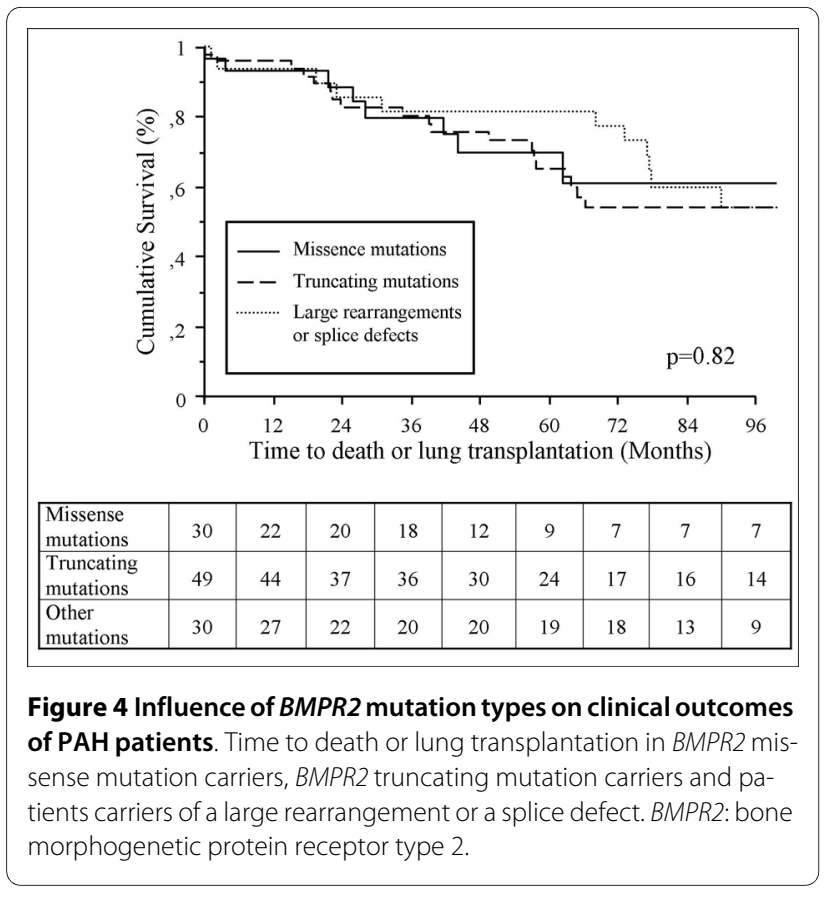

rearrangement in BMPR2 gene. Whereas Austin and colleagues [10] showed that PAH patients with missense mutations in BMPR2 gene had more severe disease than patients with truncating mutation with a significant younger age at diagnosis and a shorter survival from diagnosis to death or lung transplantation, we did not find any influence of mutation type on disease pattern or natural history among patients with BMPR2 mutation in the French PAH network. Austin and colleagues [10] hypothesized that this difference may be due to the fact that truncating mutations are degraded by nonsense-mediated decay (NMD), a mRNA surveillance mechanism that detects and degrades mRNA transcripts containing premature termination codons (PTCs), leaving only the wildtype mRNA detectable. By contrast, missense mutations escape NMD resulting in stable transcript that may produce dominant negative proteins $[19,20]$. Because some truncating mutations escape NMD, Austin et al. confirmed the activity of NMD pathway in BMPR2 truncating mutation carriers. BMPR2 truncating mutations escaping NMD pathway may represent a minority of cases, with only 7 out of the 62 BMPR2 truncating mutation carriers escaping NMD in this study [10]. Indeed, PTCs located more than 55 nucleotides upstream the last exon escape NMD. Analysis of all the truncating mutations in the French PAH network showed that 9 out of the 51 BMPR2 truncating mutation carriers had mutations predicted to escape NMD (Additional file 1). Nevertheless, if we excluded these 9 patients from the analysis of impact of $B M P R 2$ mutation type on clinical outcomes, no significant differences were seen between $B M P R 2$ missense mutation carriers, $B M P R 2$ truncating mutation carriers and patients carrying a splice defect or a large rearrangement in BMPR2 gene. However, this analysis cannot include all BMPR2 mutations that could potentially escape NMD, because it has been demonstrated that truncating mutation may also escape NMD pathway by reinitiation of translation by use of an alternative translation start site downstream the PTC, producing a BMPRII protein of a lower molecular weight $[19,20]$. Indeed, other factors may influence the relation between BMPR2 mutation type and phenotype of PAH. It has been demonstrated that the level of expression of the wild-type $B M P R 2$ allele may influence the clinical development of $\mathrm{PAH}$ in carriers of truncating BMPR2 mutations [21]. Moreover, different missense BMPR2 mutations could lead to different level of BMPRII protein expression on cell surface, depending on the level of cytosolic retention of BMPR-II transcript [22,23]. All these factors may explain the difficulty to correlate severity and penetrance of PAH to the BMPR2 mutation type.

The differences observed between our data and those reported by Austin et al. related to gender, may be explained by a selection bias with a low number of $\mathrm{PAH}$ patients without a $B M P R 2$ mutation in the cohort published by Austin et al. (only 10 male BMPR2 mutation non-carriers as compared to 79 in the French PAH Network). This low number of male patients not carrying a BMPR2 mutation may be due to a preferential recruitment of patients with a family history of PAH in the study by Austin. Indeed, $74 \%$ of their patients had such a family history, as compared to $22 \%$ in the cohort of New York Presbyterian Pulmonary Hypertension Center [5] and $20 \%$ in the French PAH network [6]. This resulted to $72 \%$ of PAH patients carrying a BMPR2 mutation in the cohort reported by Austin and colleagues, as compared to $17 \%$ in the cohort from the New York Presbyterian Pulmonary Hypertension Center [5], and 25\% in the French PAH network [6]. The lower number of BMPR2 mutation carriers in the cohort from the New York Presbyterian Pulmonary Hypertension Center [5] could be explained by the fact that patients with a considered idiopathic $\mathrm{PAH}$ were not screened for large rearrangement of $B M P R 2$. In the French PAH network, all patients with idiopathic or familial PAH were screened for point mutations and large rearrangements of $B M P R 2$ gene, to avoid selection bias.

The familial clustering in the French PAH network may explain the differences observed between our data and those reported by Austin et al. Indeed, familial clustering could impact data in terms of genes and environmental interactions that may alter disease expression beyond that of a single gene mutation. In contrast, in the French PAH network, 81 out of the 115 BMPR2 mutation carriers $(70.5 \%)$ were the only cases reported in their families, while 14 families had 2 cases reported and 2 families had 3 cases reported. Thus the majority of PAH cases we 
Table 2: Baseline hemodynamic characteristics of BMPR2 mutation carriers according to mutation types.

\begin{tabular}{|c|c|c|c|}
\hline & $\begin{array}{l}\text { BMPR2 missense } \\
\text { mutation carriers } \\
\qquad \mathrm{n}=32\end{array}$ & $\begin{array}{c}\text { BMPR2 truncating mutation } \\
\text { carriers } \\
n=51\end{array}$ & $\begin{array}{l}\text { BMPR2 large rearrangement or splice defect } \\
\text { mutation carriers } \\
\qquad n=32\end{array}$ \\
\hline $\begin{array}{l}\text { Age at diagnosis, } \\
y r s \text { (mean } \pm S D \text { ) }\end{array}$ & $35.8 \pm 16.9$ & $37.3 \pm 14.0$ & $33.5 \pm 16.3$ \\
\hline \multicolumn{4}{|l|}{ NYHA } \\
\hline$I-I I$ & $5(15.6 \%)$ & 5 (9.8\%) & $7(21.8 \%)$ \\
\hline III & $21(65.6 \%)$ & 37 (72.5\%) & $18(56.3 \%)$ \\
\hline IV & $3(9.4 \%)$ & $7(13.7 \%)$ & $6(18.8 \%)$ \\
\hline $\begin{array}{l}\text { Six-minute walk } \\
\text { test distance, } m\end{array}$ & $382 \pm 107$ & $351 \pm 91$ & $325 \pm 109$ \\
\hline mPAP, $m m H g$ & $63 \pm 14$ & $62 \pm 12$ & $62 \pm 13$ \\
\hline $\mathrm{RAP}, \mathrm{mmHg}$ & $6 \pm 5^{*}$ & $9 \pm 5$ & $8 \pm 5$ \\
\hline PCWP, $m m H g$ & $8 \pm 3$ & $7 \pm 2$ & $8 \pm 4$ \\
\hline $\mathrm{Cl}, \mathrm{L} / \mathrm{min} / \mathrm{m}^{2}$ & $2.31 \pm 0.68$ & $1.94 \pm 0.41$ & $2.16 \pm 0.75$ \\
\hline $\begin{array}{l}\text { PVRi, } m m H g / L / m i n / \\
m^{2}\end{array}$ & $24.9 \pm 10.8$ & $25.0 \pm 10.5$ & $22.5 \pm 14.9$ \\
\hline SvO2, $\%$ & $60 \pm 9$ & $57 \pm 10$ & $60 \pm 9$ \\
\hline $\begin{array}{l}\text { Acute vasodilator } \\
\text { responders, \% }\end{array}$ & $1(3.1 \%)$ & 1 (1.9\%) & 0.9 \\
\hline
\end{tabular}

${ }^{*} \mathrm{p}=0.02$ compared to $B M P R 2$ truncating mutation carriers

${ }^{\mathrm{q}} \mathrm{p}=0.01$ compared to $B M P R 2$ truncating mutation carriers

BMPR2: bone morphogenetic protein receptor type 2, PAH: pulmonary arterial hypertension, $N Y H A=$ New York Heart Association, $m P A P=m e a n$ pulmonary artery pressure, $R A P=$ right atrial pressure, $P C W P=$ pulmonary capillary wedge pressure, $C l=$ cardiac index,$P V R i=$ indexed pulmonary vascular resistance, $\mathrm{SVO} 2=$ mixed venous oxygen saturation, $\mathrm{NO}=$ nitric oxide.

Results are expressed as mean \pm SD

studied were the only reported cases from their families and familial clustering represented only a minority of reported cases.

Finally, PAH patients with a family history of PAH without identification of either BMPR2 or ACVRL1 mutation $(\mathrm{n}=13)$ were excluded from the analysis in order to limit the risk of misclassification, although their clinical and hemodynamic characteristics were broadly similar to those of BMPR2 mutation carriers (age at PAH diagnosis $38.9 \pm 12.5$ yrs, mPAP $64 \pm 13 \mathrm{mmHg}$, PVRi $25.9 \pm 9.5$ $\left.\mathrm{mmHg} / \mathrm{L} / \mathrm{min} / \mathrm{m}^{2}\right)$. Moreover, ACVRL1 and Endoglin are two other genes well known to predispose to PAH. However, similar approach was not possible in ACVRL1 and Endoglin mutation carriers because the number of patients was too low (1 male and 8 female ACVRL1 mutation carriers, and only one patient with an Endoglin mutation).
In conclusion, our data indicate that mutation type has no influence on disease pattern or natural history among patients with BMPR2 mutations. However BMPR2 mutation carriers (males or females) are younger at diagnosis with a similar evolution of the disease than non-carriers, leading to a younger age at death of $B M P R 2$ mutation carriers compared to non-carriers.

\section{Additional material}

Additional file 1 Details of BMPR2 Mutations.

\section{Abbreviations}

2-OHE: 2-hydroxyestrogens; 4-OHE: 4-hydroxyestrogens; 16a-OHE1: 16ahydroxyestrone; BMPR2: Bone morphogenetic protein receptor type 2; CYP1B1: Cytochrome P450 1B1; NMD: nonsense-mediated decay; PAH: Pulmonary arterial hypertension; PTC: Premature termination codons.

Competing interests

The authors declare that they have no competing interests. 


\section{Authors' contributions}

$B G$ and DM performed the statistical analysis and wrote the manuscript. ME, AY, $B S, F C, G S, F S$ and $M H$ helped to conception, design and wrote the manuscript. All authors read and approved the final manuscript.

\section{Author Details}

'Faculté de Médecine, Université Paris-Sud, Kremlin-Bicêtre, F-94276, France, 2 Service de Pneumologie et Réanimation Respiratoire, Centre National de Référence de l'Hypertension Pulmonaire Sévère, Hôpital Antoine Béclère, Assistance Publique-Hôpitaux de Paris, Clamart, F-92140, France, 3INSERM U999, Hypertension Artérielle Pulmonaire: Physiopathologie et Innovation Thérapeutique, Centre Chirurgical Marie-Lannelongue, Le Plessis-Robinson, F92350, France and ${ }^{4}$ Laboratoire d'Oncogénétique et Angiogénétique Moléculaire, UMRS 956 INSERM, Université Pierre et Marie Curie-Paris 6, Groupe Hospitalier Pitié-Salpétrière, Paris, F-75651, France

Received: 8 February 2010 Accepted: 10 June 2010

Published: 10 June 2010

\section{References}

1. Galie N, Hoeper MM, Humbert M, Torbicki A, Vachiery JL, Barbera JA, Beghetti M, Corris P, Gaine S, Gibbs JS, Gomez-Sanchez MA, Jondeau G, Klepetko W, Opitz C, Peacock A, Rubin L, Zellweger M, Simonneau G: Guidelines for the diagnosis and treatment of pulmonary hypertension. Eur Respir J 2009, 34:1219-63.

2. Galie N, Hoeper MM, Humbert M, Torbicki A, Vachiery JL, Barbera JA Beghetti M, Corris P, Gaine S, Gibbs JS, Gomez-Sanchez MA, Jondeau G, Klepetko W, Opitz C, Peacock A, Rubin L, Zellweger M, Simonneau G, Vahanian A, Auricchio A, Bax J, Ceconi C, Dean V, Filippatos G, FunckBrentano C, Hobbs R, Kearney P, McDonagh T, McGregor K, Popescu BA, Reiner Z, Sechtem U, Sirnes PA, Tendera M, Vardas P, Widimsky P, Sechtem U, Al Attar N, Andreotti F, Aschermann M, Asteggiano R, Benza R, Berger R, Bonnet D, Delcroix M, Howard L, Kitsiou AN, Lang I, Maggioni A, NielsenKudsk JE, Park M, Perrone-Filardi P, Price S, Domenech MT, VonkNoordegraaf A, Zamorano JL: Guidelines for the diagnosis and treatment of pulmonary hypertension: The Task Force for the Diagnosis and Treatment of Pulmonary Hypertension of the European Society of Cardiology (ESC) and the European Respiratory Society (ERS), endorsed by the International Society of Heart and Lung Transplantation (ISHLT). Eur Heart J 2009, 30:2493-537.

3. Humbert M, Sitbon O, Simonneau G: Treatment of pulmonary arterial hypertension. N Engl J Med 2004, 351:1425-36.

4. Sztrymf B, Coulet F, Girerd B, Yaici A, Jais X, Sitbon O, Montani D, Souza R, Simonneau G, Soubrier F, Humbert M: Clinical outcomes of pulmonary arterial hypertension in carriers of BMPR2 mutation. Am J Respir Crit Care Med 2008, 177:1377-83

5. Rosenzweig EB, Morse JH, Knowles JA, Chada KK, Khan AM, Roberts KE, McElroy JJ, Juskiw NK, Mallory NC, Rich S, Diamond B, Barst RJ: Clinical implications of determining BMPR2 mutation status in a large cohort of children and adults with pulmonary arterial hypertension. $J$ Heart Lung Transplant 2008, 27:668-74.

6. Girerd B, Montani D, Coulet F, Sztrymf B, Yaici A, Jais X, Tregouet D, Reis A, Drouin-Garraud V, Fraisse A, Sitbon O, O'Callaghan DS, Simonneau G, Soubrier F, Humbert M: Clinical Outcomes of Pulmonary Arterial Hypertension in Patients Carrying an ACVRL1 (ALK1) Mutation. Am J Respir Crit Care Med 2010, 181(8):851-61.

7. Trembath R, Thomson J, Machado RD, Morgan NV, Atkinson C, Winship Simonneau G, Galie N, Loyd JE, Humbert M, Nichols WC, Morrell NW: Clinical and molecular genetic features of pulmonary hypertension in hereditary hemorrhagic telangiectasia. N Engl J Med 2001, 345:325-34.

8. Harrison RE, Berger R, Haworth SG, Tulloh R, Mache CJ, Morrell NW, Aldred MA, Trembath RC: Transforming growth factor-beta receptor mutations and pulmonary arterial hypertension in childhood. Circulation 2005 111:435-41

9. Chaouat A, Coulet F, Favre C, Simonneau G, Weitzenblum E, Soubrier F, Humbert M: Endoglin germline mutation in a patient with hereditary haemorrhagic telangiectasia and dexfenfluramine associated pulmonary arterial hypertension. Thorax 2004, 59:446-8.

10. Austin ED, Phillips JA, Cogan JD, Hamid R, Yu C, Stanton KC, Phillips CA, Wheeler LA, Robbins IM, Newman JH, Loyd JE: Truncating and missense BMPR2 mutations differentially affect the severity of heritable pulmonary arterial hypertension. Respir Res 2009:10:87.
11. McGoon M, Gutterman D, Steen V, Barst R, McCrory DC, Fortin TA, Loyd JE: Screening early detection, and diagnosis of pulmonary arterial hypertension: ACCP evidence-based clinical practice guidelines. Chest 2004, 126:14S-34S

12. Humbert M, Sitbon $\mathrm{O}$, Chaouat A, Bertocchi M, Habib G, Gressin V, Yaici A, Weitzenblum E, Cordier JF, Chabot F, Dromer C, Pison C, Reynaud-Gaubert M, Haloun A, Laurent M, Hachulla E, Simonneau G: Pulmonary arterial hypertension in France: results from a national registry. Am J Respir Crit Care Med 2006, 173:1023-30.

13. Sitbon O, Humbert M, Jais X, loos V, Hamid AM, Provencher S, Garcia G, Parent $F$, Herve P, Simonneau G: Long-term response to calcium channel blockers in idiopathic pulmonary arterial hypertension. Circulation 2005, 111:3105-11.

14. Sitbon O, Humbert M, Nunes H, Parent F, Garcia G, Herve P, Rainisio M, Simonneau G: Long-term intravenous epoprostenol infusion in primary pulmonary hypertension: prognostic factors and survival. J Am Coll Cardiol 2002, 40:780-8

15. ATS Committee on Proficiency Standards for Clinical Pulmonary Function Laboratories: ATS statement: guidelines for the six-minute walk test. Am J Respir Crit Care Med 2002, 166:111-7.

16. Humbert M, Sitbon O, Chaouat A, Bertocchi M, Habib G, Gressin V, et al:: Survival in patients with idiopathic, familial, and anorexigenassociated pulmonary arterial hypertension in the modern management era. Am J Respir Crit Care Med 2010, 181:A4812.

17. West J, Cogan J, Geraci M, Robinson L, Newman J, Phillips JA, Lane K, Meyrick B, Loyd J: Gene expression in BMPR2 mutation carriers with and without evidence of pulmonary arterial hypertension suggests pathways relevant to disease penetrance. BMCMed Genomics 2008:1:45

18. Austin ED, Cogan JD, West JD, Hedges LK, Hamid R, Dawson EP, Wheeler LA, Parl FF, Loyd JE, Phillips JA: Alterations in oestrogen metabolism: implications for higher penetrance of familial pulmonary arterial hypertension in females. Eur Respir J 2009, 34:1093-9.

19. Kuzmiak HA, Maquat LE: Applying nonsense-mediated mRNA decay research to the clinic: progress and challenges. Trends Mol Med 2006, 12:306-16.

20. Harries LW, Bingham C, Bellanne-Chantelot C, Hattersley AT, Ellard S: The position of premature termination codons in the hepatocyte nuclear factor -1 beta gene determines susceptibility to nonsense-mediated decay. Hum Genet 2005, 118:214-24.

21. Hamid R, Cogan JD, Hedges LK, Austin E, Phillips JA, Newman JH, Loyd JE: Penetrance of pulmonary arterial hypertension is modulated by the expression of normal BMPR2 allele. Hum Mutat 2009, 30:649-54

22. Rudarakanchana N, Flanagan JA, Chen H, Upton PD, Machado R, Patel D, Trembath RC, Morrell NW: Functional analysis of bone morphogenetic protein type II receptor mutations underlying primary pulmonary hypertension. Hum Mol Genet 2002, 11:1517-25.

23. Nasim MT, Ghouri A, Patel B, James V, Rudarakanchana N, Morrell NW, Trembath RC: Stoichiometric imbalance in the receptor complex contributes to dysfunctional BMPR-II mediated signalling in pulmonary arterial hypertension. Hum Mol Genet 2008, 17:1683-94.

doi: 10.1186/1465-9921-11-73

Cite this article as: Girerd et al., Absence of influence of gender and BMPR2 mutation type on clinical phenotypes of pulmonary arterial hypertension Respiratory Research 2010, 11:73 